\title{
1999-2010 yılları arasında kliniğimizde takip edilen herpes zoster olgularının retrospektif değerlendirilmesi
}

\section{Retrospective evaluation of patients with herpes zoster followed up in our department between 1999-2010}

\section{Oğuz Küçükçakır, Cihangir Aliağaoğlu, Hakan Turan, Mehmet Emin Yanık, Zehra Gürlevik, Ersoy Acer, Hülya Albayrak, İbak Gönen*}

Düzce Üniversitesi Tıp Fakültesi, Deri ve Zührevi Hastalıklar Anabilim Dalı ve

*Klinik Mikrobiyoloji ve İnfeksiyon Hastalıkları Anabilim Dalı, Düzce, Türkiye

\section{Özet}

Amaç: Herpes zoster sinir sisteminin yaygın görülen viral bir hastalığıdır. Yıllık insidansı 1,5-3/1000 olmakla birlikte, 75 yaș üzerinde bu oran artmaktadır. Mevsimsel faktörlerin hastalığın insidansını etkileyebileceği düșünülmektedir. Bu çalıșmanın amacı herpes zoster tanısı almıș olan hastaların klinik, demografik özelliklerinin incelenerek, Türkiye ve dünyadaki diğer epidemiyolojik çalıșmalarla benzerlik ve farklııılarının ortaya konmasıdır.

Gereç ve Yöntemler: Çalıșmamızda Düzce Üniversitesi Tıp Fakültesi Deri ve Zührevi Hastalıklar Anabilim Dalında Ocak 1999-Aralık 2010 tarihleri arasında herpes zoster tanısı konulan 312 hastanın dosyaları retrospektif olarak değerlendirildi.

Bulgular: Kliniğimize bașvuran tüm hastaların \%0,56'sının herpes zoster hastası olduğu gözlenmiștir. Hastaların yașı 6 ay ile 87 yaș arasında değișmekteydi (ortalama 49,6; ortanca değer 53). Kadın ve erkek olgu sayısı hemen hemen eșitti. Ocak ve Ağustos aylarında bașvuru sayısı daha fazla idi. En sık torakal tutulum vardı. Herhangi bir gizli malinite öncüsü değildi. Sistemik olarak en sık kalp damar hastalıkları ile birlikteliği tespit edildi. Olguların \%7,4'ünün çocuk hasta olduğu izlendi. Hastaların \%21,4'ünde komplikasyon saptandı. En sık görülen komplikasyon postherpetik nevralji idi.

Sonuç: Herpes zoster epidemiyolojisiyle ilgili ülkemizde az sayıda çalıșma olduğu görülmektedir. Çalıșma sonuçlarımızı mevcut literatür verileriyle kıyasladığımız zaman az veya çok benzer bulguların olduğunu gözlemledik. Diğer çalıșmalardan farklı olarak en sık eșlik eden sistemik hastalık kardiyovasküler hastalıklardı. Bu durum bu tür kronik stres yapıcı faktörlerin humoral ve hücresel immüniteyi zayıflatmasına bağlanmıștır. Ülkemizin farklı bölgelerinden benzer çalıșmaların hastalı̆ı̆ı klinik ve epidemiyolojik özelliklerinin daha net șekilde ortaya çıkması için gerekli olduğunu düșünüyoruz. (Türkderm 2012; 46: 186-90)

Anahtar Kelimeler: Epidemiyoloji, herpes zoster

\section{Summary}

Background and Design: Herpes zoster is a common viral disease of the nervous system. Although the annual incidence is $1.5-3 / 1000$, this rate increases after 75 years of age. Seasonal factors are estimated to affect the incidence rate of the disease as well. The aim of this study was to investigate the clinical and demographic characteristics of patients diagnosed with herpes zoster and to explore the similarities and differences with other epidemiological studies from Turkey and the world.

Yazıssma Adresi/Address for Correspondence: Dr. Hakan Turan, Düzce Üniversitesi Tıp Fakültesi, Deri ve Zührevi Hastallklar Anabilim Dalı, Düzce, Türkiye Tel.: +90 3805421390 Gsm: +90 5333866521 E-posta: drhakanturan@gmail.com Geliş Tarihi/Received: 26.12.2011 Kabul Tarihi/Accepted: 06.02.2012 
Materials and Methods: We retrospectively reviewed the records of 312 patients diagnosed with herpes zoster and followed up in the Düzce University Medical Faculty Dermatology Department between January 1999 and December 2010.

Results: Herpes zoster patients comprised $0.56 \%$ of all patients who presented to our department. Their ages ranged from 6 months to 87 years (mean age: 49.6, median age: 53). The number of women and men was almost equal. Admissions were higher in January and December, with thoracic involvement being the most frequent one. Zoster was not a precursor of any occult malignancies. The most common associated systemic disease was cardiovascular disease. Pediatric cases comprised $7.4 \%$ of cases. Complications developed in $21.4 \%$ of patients. The most common complication was postherpetic neuralgia. Discussion: There are only a few studies from our country on the epidemiology of herpes zoster. We observed that our findings were more or less similar to the findings of the literature data. However, unlike in other studies, in our study, the most common associated systemic disease was cardiovascular disease. It is thought that this is because this kind of chronic stressor weakens humoral and cellular immunity. We think that similar studies from different regions of our country are necessary to demonstrate the clinical and epidemiological characteristics of the disease more clearly. (Turkderm 2012; 46: 186-90)

Key Words: Epidemiology, herpes zoster

\section{Giriş}

Herpes zoster varisella zoster virüsün duyusal sinir arka kök ganglionlarında saklı kalması ve hayatın ilerleyen dönemlerinde direncin düşmesine paralel olarak reaktivasyonu ile karakterize, dermatomal yerleşimli, ağrılı, veziküler bir dermatozdur1,2. Genel yıllık insidansı 1,5-3,0/1000 olmakla birlikte, 75 yaş üzerinde bu oran 10/1000'in üzerine çıkmaktadır. Yaşam boyunca hastalığı geçirme riski yaklaşık olarak \%10 ila 20'dir3,4. Güneş yanığı, stres, ateş, spinal korda fiziksel travma, radyoterapi, immünsupresif ilaç kullanımı, kanser, lösemi, lenfoma, HIV infeksiyonu, ağır metal zehirlenmeleri ve varisella virusu ile tekrar karşılaşma hastalığı tetikleyici faktörler arasındadır. Yapılan çalışmalarda hastalığın mevsimsel insidansı ile ilgili birbirinden farklı sonuçlar bildirilmiştir.

Bu çalışmada herpes zoster tanısı almış olan hastaların klinik, demografik özellikleri ve hastalığın mevsimlerle olan ilişkisi incelenerek, Türkiye ve dünyadaki diğer epidemiyolojik çalışmalarla benzerlik ve farkılıklarının ortaya konması ve literatüre katkıda bulunulması amaçlandı.

\section{Gereç ve Yöntem}

Çalışmamızda Ocak 1999-Aralık 2010 tarihleri arasında klinik olarak herpes zoster tanısı konulan 312 hastanın dosyası incelendi.

Retrospektif arşive dayalı çalışmamız için Yerel Etik Kuruldan onay alındı (Etik Kurul No: 2011/146)

Hastaların yaş ve cinsiyet bilgileri, hastalığın aylara ve mevsimlere göre dağılımı, lezyon yerleşim yeri, dermatomal dağılım, eşlik eden maliniteler, sistemik hastalıklar ve komplikasyonlar kaydedildi.

Herpes zosterli hastaların veri kayıtları tamamlandıktan sonra hastaların demografik özellikleri ile klinik özellikleri arasındaki ilişki araştırıldı.

\section{Bulgular}

Çalışmaya son 12 yılda kliniğimizde izlenen 312 herpes zoster hastası dahil edildi. Bu dönemde başvuran toplam hasta sayısının (55,616 hasta) \%0,56'sı herpes zoster olarak tanı almıştı. Hastaların yaşları 7 ay ile 87 yaş arasında değişmekte olup ortalama 49,6, ortanca değer 53 idi. Hastaların 157'si $(\% 50,3)$ kadın, 155'i $(\% 49,7)$ erkek olup erkek/kadın oranı yaklaşık olarak 1 'di.

Hastaların cinsiyete göre yaş dağılımı incelendiğinde ortalama yaş erkeklerde 48,5; kadınlarda 50,7 olarak bulundu. Hem erkek hem de kadın hastalarda en fazla hasta sayısının 6. dekatta olduğu izlendi (Tablo 1). Hastalar başvuru aylarına göre değerlendirildiğinde, Ocak (35 hasta, \%11,22) ve Ağustos (35 hasta, \%11,22) aylarında hasta başvurusunda artış gözlenmiş olup bunları Temmuz (34 hasta, \%10,9) ayı izlemiştir. En az hasta sayısı ise Nisan (10 hasta, \%3,21) ayında tespit edilmiştir. Mevsimsel olarak değerlendirildiğinde en fazla başvuru yaz (96 hasta, $\% 30,77)$ mevsiminde olup, bunu sırasıyla sonbahar (85 hasta, \%27,34) ve kış $(81$ hasta, \%25,96) mevsimleri takip etmiştir. En az başvuru ise ilkbahar (50 hasta, \%16,03) mevsiminde saptanmıştır (Tablo 2).

Yüz elli beş erkek hastanın 94'ünde $(\% 60,6)$ vücudun sağ tarafı, 60'ında $(\% 38,7)$ sol tarafı ve 1 hastada $(\% 0,7)$ bilateral tutulum saptanmıştır.

Tablo 1. Hasta sayısının dekatlara göre dağılımı

\begin{tabular}{|l|c|c|}
\hline Yaş & Sayı & $\%$ \\
\hline $0-10$ & 9 & 2,8 \\
\hline $11-20$ & 24 & 7,6 \\
\hline $21-30$ & 38 & 12,1 \\
\hline $31-40$ & 16 & 5,1 \\
\hline $41-50$ & 42 & 13,4 \\
\hline $51-60$ & 74 & 23,7 \\
\hline $61-70$ & 56 & 17,9 \\
\hline $71-80$ & 43 & 13,7 \\
\hline $81-90$ & 10 & 3,2 \\
\hline Toplam & 312 & 100 \\
\hline
\end{tabular}

Tablo 2. Hasta sayısının aylara göre dağılımı

\begin{tabular}{|l|c|c|}
\hline Aylar & Sayı & $\%$ \\
\hline Ocak & 35 & 11,2 \\
\hline Şubat & 21 & 11,2 \\
\hline Mart & 18 & 5,7 \\
\hline Nisan & 10 & 3,2 \\
\hline Mayıs & 22 & 7,0 \\
\hline Haziran & 27 & 8,6 \\
\hline Temmuz & 34 & 10,8 \\
\hline Ağustos & 35 & 11,2 \\
\hline Eylül & 30 & 9,6 \\
\hline Ekim & 28 & 8,9 \\
\hline Kasım & 27 & 8,6 \\
\hline Aralık & 25 & 8,0 \\
\hline Toplam & 312 & 100 \\
\hline
\end{tabular}


Yüz elli yedi kadın hastanın 93'ünde $(\% 59,2)$ vücudun sol tarafı, 63 ünde $(\% 40,1)$ vücudun sağ tarafı ve 1 hastada $(\% 0,7)$ bilateral tutulum saptandı. Lezyonların yerleşim yerine bakıldığında hastaların 136 'sında $(\% 43,59)$ torasik, 56'sında $(\% 17,95)$ lumbal, 45'inde $(\% 14,42)$ trigeminal, 26 'sında $(\% 8,33)$ alt ekstremite, $23^{\prime}$ ünde $(\% 7,37)$ üst ekstremite, 14 'ünde $(\% 4,49)$ servikal, $8^{\prime}$ inde $(\% 2,56)$ fasiyal, $4^{\prime}$ ünde $(\% 1,28)$ dissemine tutulum saptanmıştır (Tablo 3).

Hastaların $23^{\prime} u ̈(\% 7,4)$ çocuk hasta olup yaşları 7 ay ile 17 yaş arasında değişmekteydi (ortalama yaş 10,8). Çocuk hastaların lezyonlarının dermatomal dağılımına bakıldığında 13'ünde $(\% 56,52)$ torasik, 3 'ünde $(\% 13,04)$ trigeminal, 3 'ünde $(\% 13,04)$ alt ekstremite, 2 'sinde $(\% 8,7)$ lumbal, 1 'inde $(\% 4,35)$ servikal, 1 'inde $(\% 4,35)$ üst ekstremite tutulumu saptanmıştır (Şekil 4). Çocuk hastalarda eşlik eden herhangi bir malinite veya sistemik hastalık saptanmamıştır.

On iki hastada eşlik eden malinite mevcuttu. Bu maliniteler $3(\% 0,96)$ prostat adenokarsinomu, $3(\% 0,96)$ akciğer karsinomu, $2(\% 0,64)$ larenks karsinomu, $2(\% 0,64)$ meme karsinomu, $1(\% 0,32)$ multipl myelom ve $1(\% 0,32)$ kronik lenfositik lösemi şeklindeydi (Tablo 5).

Sistemik hastalıklar yönünden değerlendirildiğinde ise 312 hastanın 236'sında sistemik hastalık saptanmazken; 16 hastada diabetes mellitus (DM), 27 hastada hipertansiyon (HT), 3 hastada hem DM hem HT, 4 hastada kronik obstrüktif akciğer hastalığı $(\mathrm{KOAH}), 7$ hastada koroner arter hastalığı, 4 hastada konjestif kalp yetmezliği, 6 hastada hiperlipidemi, 1 hastada hipotiroidi, 1 hastada bronşiyal astım, 1 hastada akciğer tüberkülozu, 1 hastada nefrotik sendrom, 1 hastada serebrovasküler hastalık, 1 hastada kronik böbrek yetmezliği saptandı (Tablo 6).

Altmış dokuz hastada komplikasyon geliştiği görüldü. Komplikasyon dağılımı $67(\% 21,47)$ postherpetik nevralji (PHN), $2(\% 0,64)$ hastada Ramsay - Hunt Sendromu şeklindeydi.

\section{Tablo 3. Herpes zosterin tutulan alanlara göre dağılımı}

\begin{tabular}{|l|c|c|}
\hline Tutulan alan & Sayı & $\%$ \\
\hline Torasik & 136 & 43,5 \\
\hline Lumbal & 56 & 17,9 \\
\hline Trigeminal & 45 & 14,4 \\
\hline Alt ekstremite & 26 & 8,3 \\
\hline Üst ekstremite & 23 & 7,3 \\
\hline Servikal & 14 & 4,4 \\
\hline Fasiyal & 8 & 2,5 \\
\hline Disemine & 4 & 1,2 \\
\hline Toplam & 312 & 100 \\
\hline
\end{tabular}

Tablo 4. Pediyatrik zosterin tutulan alanlara göre dağıımı

\begin{tabular}{|l|c|c|}
\hline Dermatom & Sayı & $\%$ \\
\hline Torasik & 13 & 56,5 \\
\hline Trigeminal & 3 & 13,0 \\
\hline Alt ekstremite & 3 & 13,0 \\
\hline Lumbal & 2 & 8,7 \\
\hline Üst ekstremite & 1 & 4,3 \\
\hline Servikal & 1 & 4,3 \\
\hline Toplam & 23 & 100 \\
\hline
\end{tabular}

Üç yüz on iki herpes zoster hastasının sadece 12'sinde $(\% 3,85)$ hastaneye yatırılarak tedavi uygulanmasına gerek duyulmuştur.

\section{Tartışma}

Amerika Birleşik Devletleri'nde herpes zoster yıllık insidansının 3,2-3.8/1000 arasında olduğu, hastaların çoğunluğunu 60 yaşın üzerinde veya immunsüpresif bireylerin oluşturduğu bildirilmiştir5-7. Fransa'da Czernichow ve ark. 8 tarafından yapılan bir çalışmada yıllık insidans oranı 3,2/1000, Hollanda'da Opstelten ve ark. ${ }^{5}$ tarafından yapılan çalışmada 3,4/1000, Kanada'da Brisson ve ark. ${ }^{6}$ tarafından yapılan çalışmada 3.5/1,000 ve Yung-Hsiu Lin ve ark.nın7 Tayvan halkında yaptığı 5 yıllık bir çalışmada insidans oranı 4,97/1000 olarak saptanmıştır. Çalışmamızda da herpes zoster insidansı 5,6/1000 olarak saptanmıştır.

Danohue ve ark. ${ }^{9}$ herpes zosterin çoğunlukla 50 yaşın üzerinde ortaya çıktığını ve olguların yalnızca \%5'lik kısmının 15 yaşın altında olduğunu rapor etmişlerdir. Bizim çalışmamızda hastaların büyük çoğunluğu $(\% 72,11) 40$ yaş üzerindeydi. Bu durum mevcut literatür verileri ile uyumlu bulunmuştur. İleri yaşlarda hücresel ve humoral immünitedeki düşüşe bağlı olarak hastalığın insidansının arttığı düşünülmektedir10. Yung-Hsiu Lin ve ark. ${ }^{7}$ yaptıkları çalışmada hastalığın kadınlarda görülme sıklığını belirgin şekilde yüksek saptamışlardır. Zak-Prelich ve

\begin{tabular}{|l|c|l|}
\hline Tablo 5. Eşlik eden maliniteler \\
\hline Malinite & Sayı & $\%$ \\
\hline Prostat & 3 & 0,9 \\
\hline Akciğer & 3 & 0,9 \\
\hline Larenks & 2 & 0,6 \\
\hline Meme & 2 & 0,6 \\
\hline Multipl myelom & 1 & 0,3 \\
\hline KLL & 1 & 0,3 \\
\hline Toplam & 23 & 3,6 \\
\hline
\end{tabular}

Tablo 6. Eşlik eden sistemik hastalıklar

\begin{tabular}{|l|c|c|}
\hline Sistemik Hastalık & Sayı & $\%$ \\
\hline HT & 27 & 8,6 \\
\hline DM & 16 & 5,1 \\
\hline KAH & 7 & 2,2 \\
\hline Hiperlipidemi & 6 & 1,9 \\
\hline KKY & 4 & 1,2 \\
\hline KOAH & 4 & 1,2 \\
\hline DM/HT & 3 & 0,9 \\
\hline Hipotroidi & 1 & 0,3 \\
\hline Astma & 1 & 0,3 \\
\hline Tbc & 1 & 0,3 \\
\hline SVO & 1 & 0,3 \\
\hline Nefrotik Sendrom & 1 & 0,3 \\
\hline KRY & 1 & 0,3 \\
\hline Toplam & 76 & 24,3 \\
\hline
\end{tabular}


ark. ${ }^{11}$ ise erkeklerde daha sık görüldüğünü bildirmişlerdir. Weinberg ${ }^{12}$ herpes zosterin her iki cinsiyeti eşit olarak etkilediği sonucuna ulaşmıştır. Ülkemizden yapılan bir çalışmada ise 132 hastadan 70'i erkek (\%53), 62 'si kadın (\%42) olarak saptanmıştır13. Bizim çalışmamızda da kadın/erkek oranı yaklaşık eşit saptanmıştır.

Zak-Prelich ve ark. ${ }^{11}$ baş ve yüz gibi güneşe daha sık maruz kalan alanlarda, güneş ışınları ile hastalığın ortaya çıkması arasında anlamlı ilişki tespit etmişler ve hastalığın Temmuz ve Ağustos aylarında pik yaptığını vurgulamışlardır. Herpes zosterin yaz mevsimindeki insidans artışı UV radyasyonun hücresel immünitede yaptığı süpresyona bağlanmıştır. Saçar ve ark. ${ }^{14}$ hastalığı en sık olarak sonbahar mevsiminde ve Eylül ayında tespit etmişlerdir. Toyama ve ark. ${ }^{15}$ 48,388 herpes zoster hastası ile en geniş çalışmayı yapmış olup hastalığın Ağustos ayında pik yaptığını bildirmişlerdir. Bizim çalışmamızda gözlenen Ağustos ayındaki olgu artışı UV radyasyonun hücrese immünitede yaptığı süpresyona, Ocak ayındaki olgu sayısında artış da hava sıcaklıklarındaki düşüşün yine immüniteyi baskılamasına bağlanmıştır. Mevsimsel farklıkları tam olarak ortaya koyabilmek için daha geniş olgu serili bölgesel hatta ülke çapında çalışmalara ihtiyaç olduğu kesindir.

Herpes zosterde genellikle tek dermatom tutulur. Fakat neden vücudun bir yarısının tutulduğu tam olarak bilinmemektedir. Ülkemizden yapılan iki ayrı çalışmada erkek hastaların vücudunun sağ tarafının, kadın hastaların ise sol tarafının daha fazla tutulduğu gösterilmiştir16,17. Bizim çalışmamızda da benzer veriler elde edilmiştir. Dane ve ark. ${ }^{18}$ vücudun sol tarafında hücre aracılı hipersensitivitenin vücudun sağ tarafından daha kuvvetli olduğunu bildirmişlerdir. Erdem ve ark. ${ }^{17}$ herpes zosterli kadın ve erkek hastalarda tutulmuş ve tutulmamış alanlar arasında hücre aracılı immünite açısından fark olup olmadığını her iki kola PPD testi yaparak araştırmışlardır. Sonuç olarak tüberkülin reaksiyonunun vücudun tutulan alanında tutulmamış alanına göre daha düşük olduğu ve bu durumun herpes zoster infeksiyonunun niçin tek taraflı olarak ortaya çıktığını açıklayabileceği sonucuna varmışlardır. Çalışmamızda ayrıca hastaların ikisinde $(\% 0,64)$ bilateral tutulum saptanmıştır. Bunlardan birisi 60 yaşında erkek hasta olup immün supresyon nedeni olarak nefrotik sendrom saptanmıştır. Bilateral tutulum saptanan diğer hasta ise 24 yaşında kadın hasta olup immünsupresyona neden olabilecek herhangi bir hastalık saptanmamıştır.

Herpes zosterde en sık torasik tutulumun olduğu bildirilmiştir4,12. Bizim çalışmamızda da hastaların lezyonlarının dermatomal dağılımına bakıldığında, en sık torasik bunu takiben de lumbal tutulumun olduğu görülmüştür.

Herpes zoster erişkine kıyasla daha az sıklıkta olmakla birlikte pediyatrik popülasyonda da gözlenmektedir9. Terada ve ark. ${ }^{19}$ tarafından yapılan çalışmada çocuklarda gözlenen herpes zoster infeksiyonunun hafif ateş ve ağrı sebebi olabildiği, en sık torasik dermatomlarda gözlendiği, erişkin hastalara zıt olarak kraniyal sinirlerin nadiren etkilendiği, sakral bölge tutulumu ve disseminasyonun da nadir gözlendiği ve PHN'nin az sayıda olguda geliştiği bildirilmiştir. Yapılan çalışmalarda pediyatrik zosterin altta yatan herhangi bir malinite ile ilişkili olmadığı bildirilmiştir20. Bizim çalışmamızda da çocuk hasta oranı \%7,4 olup en sık torasik tutulum gözlenmiştir ve hastaların hiçbirinde altta yatan bir malinite ve PHN saptanmamıştır.

Herpes zoster en sık hematolojik olmak üzere çeşitli internal maliniteler ile eş zamanlı olarak ortaya çıkabilir. Lezyonların çok nadiren malinite öncüsü olduğu, sıklıkla mevcut maliniteye eşlik eder şekilde ortaya çıktığı bildirilmiştir ${ }^{21}$. Fueyo ve ark.22 yaptıkları çalışmada herpes zoster'in gizli malinite için bir belirteç olmadığını, bu hastalarda malinite riskinin genel popülasyonla aynı olduğunu bildirmişlerdir. Soyuncu ve ark. da12 132 hastanın 8'inde $(\% 6,1)$ eșlik eden malinite olduğunu, fakat zosterin hiçbir hastada malinitenin öncü belirtisi olmadığını saptamışlardır. Bizim çalışmamızda eşlik eden maligite oranı \%3,84 bulunmuş ve hastalığın her hangi bir maliniteye öncülük etmediği tespit edilmiştir. Sonuç olarak herpes zosterin gizli maliniteler için iyi bir belirteç olmadığı görülmektedir. Bu nedenle her hastanın değil, anamnez ve fizik muayene bulgularında şüphe olan hastaların gizli malinite için ayrıntılı olarak tetkik edilmesi gerektiğini düşünmekteyiz.

Çalışmamızda herpes zosterin en sık HT, ardından DM ve kalp hastalıklarına eşlik ettiği göze çarpmaktadır. Kardiyovasküler disregülasyon ile depresyonun ilişkili olması23, ${ }^{2} T^{\prime}$ nin yaşam kalitesi üzerine olan negatif etkileri24 ve bu tür kronik stres yapıcıların hem hücresel hem humoral immüniteyi bozması25; DM'nin ve özellikle kontrolsüz diyabetin hücresel immünüteyi bozması26 nedeniyle bu hastalıkların diğer sistemik hastalıklara göre daha ön plana çıktığını düşünmekteyiz.

Schmader27 yaptığı çalışmada PHN'nin, genel popülasyonda herpes zoster geçirenlerin \%34'ünde gözlendiğini, fakat 60 yaş ve üstündeki hastalarda bu oranın \%60-70'lere çıktığını bildirmiştir. Bizim çalışmamızda ise Schmader'in 27 çalışmasından farklı olarak PHN $\% 21,47$ oranında saptanmış olup bu oran 60 yaş üstü hastaların \%32'sine tekabül etmektedir. Hastaların minimum yaşı 24, maksimum yaş ise 85 olarak bulunmuştur.

Oftalmik herpes zosterin, herpes zosterli hastaların \%10 ila 20'sini etkilediği ve antiviral tedavi kullanmayan oftalmik herpes zosterli hastaların yaklaşık \%50'sinde de oküler komplikasyon olduğu bildirilmiştir28. Bizim çalışmamızda 45 hastada oftalmik tutulum saptanmış olup hiçbirinde komplikasyon görülmemiştir.

Tayvan halkında yapılan 5 yıllık bir çalışmada hospitalizasyon oranınının \%2,93 olduğu bildirilmiştir. Yine bir yaşından küçük infantlarda hospitalizasyon oranının bir yaşından büyük çocuklara göre daha fazla olduğunu, ancak bir yaşından sonra yaşla birlikte hastaneye yatış oranın arttığını bildirmişlerdir7. Bizim çalışmamızda hastaneye yatış oranı \%3,8 olarak saptanmıştır. Hastanede yatırılarak tedavi edilen hastaların hepsi erişkin hasta olup, pediyatrik hastalarda yatıılarak tedavi saptanmamıştır. Sonuç olarak herpes zosterin klinik ve epidemiyolojik özellikleriyle ilgili ülkemizde az sayıda çalışma olduğu görülmektedir. Çalışmamız Düzce yöresindeki herpes zosterli olguların klinik ve epidemiyolojik özelliklerini ortaya koymaktadır. Literatür verileriyle kıyasladığımız zaman az veya çok benzer bulguların olduğunu gözlemledik. Ülkemizin farkı bölgelerinden benzer çalışmaların hastalığın klinik ve epidemiyolojik özelliklerinin daha net şekilde ortaya çıkması için gerekli olduğunu düşünüyoruz.

\section{Kaynaklar}

1. Gilden DH, Cohrs RJ, Mahalingam R: Clinical and molecular pathogenesis of varicella virus infection. Viral Immunol 2003;16:243-58.

2. Gershon AA: Varicella-zoster virus infections. Pediatr Rev 2008;29:5-10.

3. Straus SE, Oxman MN: Varicella and Herpes Zoster. Dermatology in General Medicine'de. Ed. Fitzpatrick TB, Eisen AZ, Wolf K ve ark. 5. Baskı. New York, McGraw-Hill, 1999: 2427-50.

4. James WD, Berger TG, Elston DM: Viral Diseases. Andrews' Diseases of Skin: Clinical Dermatology'de. 10. Baskı. Toronto, Saunders Elsevier, 2006;367-415. 
5. Opstelten W, Mauritz JW, de Wit NJ, et al: Herpes zoster and postherpetic neuralgia: incidence and risk indicators using a general practice research database. Fam Pract 2002;19:471-5.

6. Brisson M, Edmunds WJ, Law B, et al: Epidemiology of varicella zoster virus infection in Canada and the United Kingdom. Epidemiol Infect 2001;127:305-14.

7. Lin YH, Huang LM, Chang IS, et al: Disease burden and epidemiology of herpes zoster in pre-vaccine Taiwan. Vaccine 2010;28:1217-20.

8. Czernichow S, Dupuy A, Flahault A, Chosidow O: Herpes zoster: incidence study among "sentinel" general practitioners. Ann Dermatol Venereol 2001;128:497-501.

9. Donahue JG, Choo PW, Manson JE, Platt R: The incidence of herpes zoster. Arch Intern Med 1995;155:1605-9.

10. Sørensen OS, Haahr S, Møller-Larsen A, Wildenhoff K: Cell-mediated and humoral immunity to herpesviruses during and after herpes zoster infections. Infect Immun 1980;29:369-75.

11. Zak-Prelich M, Borkowski JL, Alexander F, Norval M: The role of solar ultraviolet irradiation in zoster. Epidemiol Infect 2002;129:593-7.

12. Weinberg JM: Herpes zoster: epidemiology, natural history, and common complications. J Am Acad Dermatol 2007;57:130-5.

13. Soyuncu $S$, Berk $Y$, Eken $C$, et al: Herpes zoster as a useful clinical marker of underlying cell-mediated immune disorders. Ann Acad Med Singapore 2009;38:136-8

14. Saçar T, Saçar H: Seboreik Dermatit, Herpes Zoster ve Pitriyazis Rozea'nın Mevsimlere Göre Dağılımının Karşılaştırılması. Turkderm 2010;44:65-8.

15. Toyama N, Shiraki K: Society of the Miyazaki Prefecture Dermatologists: Epidemiology of herpes zoster and its relationship to varicella in Japan: A 10-year survey of 48,388 herpes zoster cases in Miyazaki prefecture. J Med Virol 2009;81:2053-8
16. Ertunç V, Dane S, Karakuzu A, Deniz O: Higher herpes zoster infection frequency in right-handed patients and more frequent appearance in the left body side of females. Acta Derm Venereol 1997;77:245.

17. Erdem T, Dane S, Kadi M: Cell-mediated immune hypersensitivity is stronger on noninvolved side than involved side in patients with herpes zoster. Int J Neurosci 2003;113:1081-6.

18. Dane S, Erdem T, Gümüştekin K: Cell-mediated immune hypersensitivity is stronger in the left side of the body than the right in healthy young subjects. Percept Mot Skills 2001;93:329-32.

19. Terada K, Kawano S, Yoshihiro K: Characteristics of herpes zoster in otherwise normal children. Pediatr Infect Dis J 1993;12:960-1.

20. Feder HM Jr, Hoss DM: Herpes zoster in otherwise healthy children. Pediatr Infect Dis J 2004;23:451-7

21. Smith JB, Fenske NA: Herpes zoster and internal malinancy. South Med J 1995;88:1089-92.

22. Fueyo MA, Lookingbill DP: Herpes zoster and occult malignancy. J Am Acad Dermatol 1984;11:480-2.

23. Grippo AJ, Johnson AK: Biological mechanisms in the relationship between depression and heart disease. Neurosci Biobehav Rev 2002:26:941-62.

24. Trevisol DJ, Moreira LB, Kerkhoff A, et al: Health-related quality of life and hypertension: a systematic review and meta-analysis of observational studies. J Hypertens 2011;29:179-88.

25. Segerstrom SC, Miller GE: Psychological stress and the human immune system: a meta-analytic study of 30 years of inquiry. Psychol Bull 2004;130:601-30.

26. Paknys G, Kondrotas AJ, Kevelaitis E: Diabetes mellitus and cellular immunity. Medicina (Kaunas) 2006:42:1-10.

27. Schmader K: Herpes zoster in older adults. Clin Infect Dis 2001;32:1481-6.

28. Liesegang TJ: Herpes zoster ophthalmicus natural history, risk factors, clinical presentation, and morbidity. Ophthalmology 2008;115:3-12. 